\title{
Bioconversion of paper mill sludge to bioethanol in the presence of accelerants or hydrogen peroxide pretreatment
}

Raghu Nandan Gurram ${ }^{\mathrm{a}}$, Mohammad Al-Shannag ${ }_{\mathrm{c}}^{\mathrm{b}}$, Nicholas Joshua Lecher ${ }^{\mathrm{a}}$, Shona M. Duncan ${ }^{\mathrm{a}}$, Eric Lawrence Singsaas ${ }^{\mathrm{c}}$ and Malek Alkasrawi ${ }^{\mathrm{a}, \mathrm{c}}$

${ }^{a}$ Wisconsin Institute for Sustainable Technology, University of Wisconsin - Stevens Point, 2001

Fourth Avenue, Stevens Point, WI, 54481

${ }^{b}$ Department of Chemical Engineering, The University of Jordan, 11942 Amman, Jordan

${ }^{c}$ Department of Paper Science and Engineering, University of Wisconsin, Stevens Point, USA

* Corresponding author Address: Department of Paper Science and Engineering, University of Wisconsin, Stevens Point, USA, E-mail: Malek.Alkasrawi@uwsp.edu

\begin{abstract}
Abbreviations: c-PAM, Cationic polyelectrolyte; PMS, Paper mill sludge; SHF, Separate hydrolysis and fermentation; SSCF, Simultaneous saccharification and fermentation; SL, Solids loading; XP-16, XP 10016; XP-20, XP 10020; (v/w), g mass/100 ml; $A_{i}$, Ash content of the initial; sludge (\%); $A_{f}$, Ash content of chemical treated or fractionated fiber rich streams (\%); $C$, Glucose concentration $\left(\mathrm{g} \mathrm{dm}^{-3}\right) ; C_{e}$, Glucose concentration at equilibrium $\left(\mathrm{g} \mathrm{dm}^{-3}\right) ; C_{a i}, \mathrm{CaCO}_{3}$ content of the initial sludge (\%); $C_{a f}, \mathrm{CaCO}_{3}$ content of chemical treated or fractionated fiber rich streams (\%); FL, Arithmetical mean fiber length $(\mu \mathrm{m}) ; l_{i}$, Mean length of fibers in the given batch; $z_{i}$, Number of fibers in a given batch of length; $r \mathrm{G}$, Production rate of glucose $\left(\mathrm{g} \mathrm{dm}^{-3} \mathrm{~h}^{-}\right.$ $\left.{ }^{1}\right) ; t$, Hydrolysis time (h); $k$, Pseudo first-order rate constant given in Eq. (5) $\left(\mathrm{h}^{-1}\right)$
\end{abstract}




\begin{abstract}
In this study we investigated the technical feasibility of convert paper mill sludge into fuel ethanol. This involved the removal of mineral fillers by using either chemical pretreatment or mechanical fractionation to determine their effects on cellulose hydrolysis and fermentation to ethanol. In addition, we studied the effect of cationic polyelectrolyte (as accelerant) addition and hydrogen peroxide pretreatment on enzymatic hydrolysis and fermentation. We present results showing that removing the fillers content (ash and calcium carbonate) from the paper mill sludge increases the enzymatic hydrolysis performance dramatically with higher cellulose conversion at faster rates. The addition of accelerant and hydrogen peroxide pretreatment further improved the hydrolysis yields by $16 \%$ and $25 \%$ (g glucose / g cellulose), respectively with the de-ashed sludge. The fermentation process of produced sugars achieved up to $95 \%$ of the maximum theoretical ethanol yield and higher ethanol productivities within $9 \mathrm{~h}$ of fermentation.
\end{abstract}

Keywords: paper mill sludge; fillers; enzymatic hydrolysis; cationic polyelectrolytes; hydrogen peroxide. 


\section{Introduction}

Renewable fuels such as ethanol, butanol, biodiesel, and bio-gasoline have received considerable attention as potential replacements for petroleum-derived products. Recent research and development for producing renewable products has concentrated on utilizing abundant lignocellulosic biomass as opposed to conventional agricultural crop-based raw materials such as cornstarch and sugar cane avoiding the "food versus fuel" debate. However, development of an efficient and cost-effective biorefinery process has been challenging due to the complex structure of the lignocellulosic material that needs extreme mechanical and chemical pretreatments (Wingren et al., 2003).

Paper mill sludge (PMS) is a solid by-product of the pulping and paper-making process, produced in large quantities of about 300-350 million tons every year (Ioelovich, 2014). Over 50 $\%$ of the PMS produced is currently being landfilled at a cost of $\$ 30$ per wet ton which represents a significant cost of around $60 \%$ of the total waste water treatment plant operating costs, creating both economical and environmental problems (Chen et al., 2014a). Alternatives to landfill disposal are being aggressively pursued by many paper companies and are specified as a research priority in Agenda 2020 for America’s Forest, Wood, and Paper Industry (Cooper \& Erickson, 1994). Biochemical conversion of PMS is attractive, relative to other options for waste management (Ioelovich, 2014). PMS contains 25-75\% carbohydrate content and offers distinct advantages as a raw material for biofuel production which includes: i) negative feedstock cost, ii) no requirement for high temperature chemical and mechanical pretreatment (as the lignin structure and content of the biomass has already been disrupted and removed during the pulp making process) making it amenable to enzymatic hydrolysis, iii) no additional unit operations are required to remove inhibitory compounds (as the PMS is freed of inhibitors during the 
primary clarification step) iv) potential integration of process into a preexisting industrial infrastructure at the paper mill, and v) can greatly alleviate economic and environmental impacts (Chen et al., 2014b). Because of these features, PMS is a very attractive feedstock for an emerging biorefining industry based on a biochemical conversion pathway featuring enzymatic hydrolysis and fermentation process to produce biofuels (Machani et al., 2014).

Cellulases (a complex cocktail of at least three different enzymes; exoglucanases, endoglucanases, and $\beta$-glucosidases) used in enzymatic hydrolysis plays a significant role in the overall process rates, yields and costs because of its high specificity towards conversion of cellulose to fermentable sugars (Wingren et al., 2003). The presence of fillers and impurities such as $\mathrm{CaCO}_{3}$, kaolin or clay, $\mathrm{TiO}_{2}, \mathrm{SiO}_{2}$, and $\mathrm{Al}_{2}\left(\mathrm{SO}_{4}\right)_{3}$ associated with cellulosic fibers can inhibit cellulase activity, thus making PMS a challenging feedstock for biofuel production. Previous studies show that enzymatic hydrolysis of PMS has been inefficient due to the inactive binding of cellulase by $\mathrm{CaCO}_{3}$ and clay decreasing enzyme digestibility of cellulose fiber in PMS, resulting in low hydrolysis yields (8-32\% g glucose / g cellulose) (Cao et al., 2012). By de-ashing (removing $\mathrm{CaCO}_{3}$ ) through various chemical pretreatment of primary sludge it was shown that the enzyme hydrolysis of carbohydrate conversion to monosaccharides in pretreated material could be increased up to $88 \%$ (g glucose / g cellulose) (Cátia V. T. et al., 2012). In another study (Kang et al., 2011) the fractionation of PMS using flotation and screening with air and 100-mesh screens, showed a $10 \%$ (g ethanol / g glucose) improvement in ethanol yields at an enzyme dosage of $10 \mathrm{FPU} / \mathrm{g}$ glucan in a simultaneous saccharification and co-fermentation (SSCF) process. A similar study by Chen et al. (2014a) showed that by fractionating recycled copy paper, enzyme hydrolysis of the fractionated material containing $0.6 \%$ (g ash/ g oven dry sludge) ash content produced approximately $40 \%$ (g glucose / g cellulose) higher sugar than 
unfractionated material at 4 Filter paper units (FPU)/oven dry (OD) $g$ of substrate enzyme dosage. Therefore, in order to achieve higher efficiency in enzymatic hydrolysis, chemical pretreatment or mechanical fractionation is required prior to enzymatic hydrolysis.

The estimated cost of cellulases accounts for approximately $20 \%$ of the total cost of a biomass-to-biorenewable fuel production process, which is considered as a major barrier to the economic commercialization of lignocellulosic biorefining (Wingren et al., 2003). Although recent biotechnological advances have lowered the cost of cellulase production, it is still a significant component of the overall biofuel process cost. In addition to efforts to lower the cost of cellulase production, lowered cellulase dosage while maintaining higher sugar yields is also an important objective. Recent research has shown that the addition of cationic polyelectrolytes (cPAM) improves enzymatic hydrolysis performance by promoting cellulase binding to cellulose fibers through "patching mechanism" (Haynes et al., 2013). On the other hand, pretreatment of lignocellulosic material by hydrogen peroxide increases the enzymatic digestibility up to 90-95 $\%$ by dissolving the lignin and exposing cellulose and hemicellulose to enzyme attack (Correia et al., 2013). The improvement in enzymatic hydrolysis yields by c-PAM and $\mathrm{H}_{2} \mathrm{O}_{2}$ can be used to reduce the enzyme dosage and processing time, thus decreasing the overall process costs.

This study explores two different de-ashing methods, chemical pretreatment and mechanical fractionation, for removal of ash from the primary PMS. Following de-ashing, the effect of two cationic polymers and hydrogen peroxide pretreatment on enzymatic hydrolysis and fermentation were evaluated with respect to the performance parameters (rates, yields, and productivities). We studied different solids loadings using chemically pretreated primary sludge for process optimization. Statistical analysis evaluated the individual effect of de-ashing, enzyme 
accelerants addition, and hydrogen peroxide pretreatment on both enzymatic hydrolysis and fermentation efficiency.

\section{Material and Methods}

\subsection{Paper mills sludge (PMS) description}

This research was performed on four PMS samples (A, B, C and D) collected from local and regional paper mills. PMS A and C obtained from two mills in central Wisconsin area $44^{\circ} 23^{\prime} 12^{\prime \prime} \mathrm{N} 89^{\circ} 49^{\prime} 23^{\prime \prime} \mathrm{W}$ and $44^{\circ} 17^{\prime} \mathrm{N} 88^{\circ} 16^{\prime} \mathrm{W}$ both mills use Kraft mill pulping system. Kraft mill process treats softwood chips (Red Pine) with a mixture of sodium hydroxide and sodium sulfide. Sludge A or C are obtained as rejects from screening the cooked pulp with screw press to obtain the pure pulp for paper making. PMS B obtained from a Kraft recycle paper mill in the Lake Minnesota /Superior/ region $\left(46^{\circ} 47^{\prime} 12.98^{\prime \prime} \mathrm{N} 92^{\circ} 5^{\prime} 53.5^{\prime \prime} \mathrm{W}\right)$ that uses Kraft and recycled paper. PMS B was obtained as rejects after screw separation of digestion-recycled while obtain pulp for papermaking. PMS D obtained from a dissolving wood pulp sulfite specialty fiber mill in Washington State $\left(46^{\circ} 57^{\prime} 19^{\prime \prime} \mathrm{N} 123^{\circ} 46^{\prime} 23^{\prime \prime} \mathrm{W}\right)$ by dissolving softwood pulp (Hemlock) in sulfite mill. PMS D obtained after mechanical separation of the pure pulp.

All the PMS samples were collected from the primary screw press after the first stage of the wastewater treatment during the summer of 2014 and stored in sealed buckets at $4{ }^{\circ} \mathrm{C}$ until further use.

The chemical composition of the PMS was determined by using laboratory analytical procedures (LAP) developed by the National Renewable Energy Laboratory (NREL) (Sluiter et al., 2010). Prior to de-ashing, all PMS samples were subjected to enzymatic hydrolysis with enzymatic loading as described in the hydrolysis section. 


\subsection{De-ashing of Primary Sludge}

Chemical or mechanical pretreatments were employed to remove ash from the primary sludge. For the chemical pretreatment, $10 \% \mathrm{w} / \mathrm{v}$ of primary sludge was mixed with $1 \mathrm{M} \mathrm{HCl}$ solution stirred overnight at $500 \mathrm{rpm}$. Calcium carbonate is one of the major fillers in the PMS and can be removed as calcium chloride when treated with hydrochloric acid according:

$$
2 \mathrm{HCl}+\mathrm{CaCO}_{3} \rightarrow \mathrm{CaCl}_{2}+\mathrm{CO}_{2}+\mathrm{H}_{2} \mathrm{O}
$$

The acid washed PMS fibers were filtered and washed with distilled water until $\mathrm{pH}$ was neutralized from 1.12 to 5.00 (the optimum $\mathrm{pH}$ for cellulolytic enzymes).

Mechanical pretreatment of the paper sludge was conducted using a Pulmac Masterscreen (Pulmac International, Montpelier, VT, USA) according to Chen et al. (2014a) with the following modifications. Ten g oven dry of PMS sample was dispersed in $500 \mathrm{~mL}$ distilled water using a standard disintegrator (Labtech Instruments Inc, Laval, Canada) for $5 \mathrm{~min}$ at 11,500 rpm. The PMS suspension was loaded into the Masterscreen with program tuned for faster cleaning and screening of PMS. Two fiber streams were obtained after fractionation: i) primary fiber that would not pass through the $0.2 \mathrm{~mm}$ hole screen and was retained on the tray and ii) secondary fiber rejects that passed through the first screen and were retained on the 200-mesh $(0.074 \mathrm{~mm}$ opening) screen. The two fiber streams were dried overnight in an oven at $105^{\circ} \mathrm{C}$ prior to ash tests as described in previous section. Ash removal or de-ashing efficiency was measured:

Ash removal $=\frac{A_{i}-A_{f}}{A_{i}}$

Where $A_{i}$ and $A_{f}$ are the ash content of the initial PMS and after chemical treatment or fractionated (fiber rich streams), respectively. 


\subsection{Enzymatic hydrolysis of sludge with accelerants and $\mathrm{H}_{2} \mathrm{O}_{2}$ pretreatment}

All enzyme hydrolysis experiments were performed using a commercial secondgeneration cellulase cocktail Cellic ${ }^{\circledR} \mathrm{CTec} 2$ (supplied by Novozymes A/S, Bagsvaerd, Denmark) at a dosage of $3.4 \mathrm{~g}$ enzyme/100 g dry PMS (3.4\%). The protein concentration of the Cellic ${ }^{\circledR}$ CTec2 was $73.6 \mathrm{mg} / \mathrm{mL}$ measured using the Bradford Coomassie Blue method and activity was 113.8 FPU per ml measured using NREL LAP standard procedure TP-510-42628. A $5 \%$ (dry w/v) suspension of each PMS with/out chemical de-ashing was prepared in citrate buffer (0.05 $\mathrm{M}, \mathrm{pH}$ 5.0) at a total working volume of $150 \mathrm{~mL}$. Two different cationic polyacrylamide(c-PAM) accelerants, XP10016: high MW and XP10020: low MW (from AlkazoNobel) with cationicity $30 \%$ and $100 \%$, respectively were individually added to the fiber suspension at $0.1 \%$ (g polymer/g dry PMS) as described by Haynes et al. (2013). The descriptors of the c-PAMs are commercial designations. As the intent was to rank the relative effects of the polyelectrolytes during the hydrolysis no attempt was made to optimize the dosage or conditions. In an additional hydrolysis experiments each PMS with and without chemical de-ashing was impregnated with 1 $\% \mathrm{H}_{2} \mathrm{O}_{2}$ (35\% concentrated solution) at $30{ }^{\circ} \mathrm{C}$ overnight and used as the starting material. For the solids loading optimizations experiments, chemical de-ashed mill A PMS was tested at different solids loading $2.5,5,10$, and $20 \%$ (w/v). In all experiments, enzymatic hydrolysis was performed at $50{ }^{\circ} \mathrm{C}$ in $250 \mathrm{~mL}$ Erlenmeyer flasks shaking at $200 \mathrm{RPM}$ for $72 \mathrm{hrs}$. Five hundred microliter samples were taken every 3 hours to monitor glucose concentration. All of the hydrolysis experiments were run in triplicate. For the fermentation experiments, enzymatic hydrolysis was performed at $10 \%(\mathrm{w} / \mathrm{v})$ solids loading and the final hydrolyzate was filtered through Whatman binder-free glass microfiber filter (Fisher Science, Pittsburgh, PA). The solids free sugar solution was stored at $4{ }^{\circ} \mathrm{C}$ until fermentation. 


\subsection{Fermentation}

Industrial yeast FermPro TM (purchased from Ferm Solutions Inc., Danville, KY) was used for the ethanol fermentation experiments. One $\mathrm{mL}$ of frozen yeast concentrate was precultured for 16 hours at $37^{\circ} \mathrm{C}$ in yeast peptone dextrose (YPD) media containing $20 \mathrm{~g} / \mathrm{L}$ glucose, $20 \mathrm{~g} / \mathrm{L}$ peptone and $10 \mathrm{~g} / \mathrm{L}$ yeast extract. The solid free PMS sugar solution was supplemented with additional nutrients according to Tanner (2007); $10 \mathrm{~g} / \mathrm{L} \mathrm{KH} 2 \mathrm{PO}_{4}, 20 \mathrm{~g} / \mathrm{L} \mathrm{MgSO}{ }_{4} \cdot 7 \mathrm{H}_{2} \mathrm{O}, 4$ $\mathrm{g} / \mathrm{L} \mathrm{CaCl}_{2} \cdot 2 \mathrm{H}_{2} \mathrm{O}, 200 \mathrm{mg} / \mathrm{L} \mathrm{ZnSO}{ }_{4} \cdot 7 \mathrm{H}_{2} \mathrm{O}, 20 \mathrm{mg} / \mathrm{L} \mathrm{Na}_{2} \mathrm{MoO}_{4} \cdot 2 \mathrm{H}_{2} \mathrm{O}, 200 \mathrm{mg} / \mathrm{L} \mathrm{CoCl}{ }_{2} \cdot 2$ $\mathrm{H}_{2} \mathrm{O}, 2 \mathrm{mg} / \mathrm{L}$ d-biotin, $5 \mathrm{mg} / \mathrm{L}$ p-aminobenzenoic acid, $5 \mathrm{mg} / \mathrm{L}$ Nicotinic acid, $5 \mathrm{mg} / \mathrm{L}$ calcium pantothenate, $10 \mathrm{mg} / \mathrm{L}$ Pyridoxine- $\mathrm{HCl}, 5 \mathrm{mg} / \mathrm{L}$ Thiamine- $\mathrm{HCl}$, and $10 \mathrm{mg} / \mathrm{L}$ lactoside. When necessary, the $\mathrm{pH}$ was adjusted to 5.0 using $\mathrm{H}_{2} \mathrm{SO}_{4}$ or $\mathrm{NaOH}$ and then the nutrient rich PMS sugar solution was filtered through a $0.2 \mu \mathrm{m}$ filter. Fermentation was carried out in $500 \mathrm{~mL}$ mini bioreactors (BioBundle Applikon Biotechnology, Foster City, CA) in triplicate with a total working volume of $350 \mathrm{~mL}$. The $\mathrm{pH}$ probes were calibrated (using two point calibration with $\mathrm{pH}$ 4 and 7 buffer solutions) before sterilization. The complete fermenter assembly with nutrient rich sugar solution was sterilized at $121^{\circ} \mathrm{C}$ for 20 minutes in an autoclave (Tuttnauer/Brinkmann VWR International, Arlington Heights, IL). When the medium cooled down to $37^{\circ} \mathrm{C}$, the dissolved oxygen (DO) probe was calibrated (to $100 \%$ ) after stabilization with air flow at 1.0 $\mathrm{mL} \min ^{-1}$ for six hours. The nutrient rich sugar solution was inoculated with the $16 \mathrm{~h}$ pre-culture of FermPro yeast at a $10 \%$ (v/v) level ( 0.4 g dry wt /L) aseptically through inoculum port. Fermentation experiments were performed at $\mathrm{pH} 5.0,37^{\circ} \mathrm{C}$, and $200 \mathrm{RPM}$ with $\mathrm{DO}$ value set to $10 \%$. $\mathrm{pH}$ was adjusted with automatic periodic addition of $1 \mathrm{M}$ sodium hydroxide solution. $2 \mathrm{~mL}$ aliquots were drawn from the sample port every $3 \mathrm{~h}$ for 24 hours using sterile $3 \mathrm{~mL}$ syringes for 
analysis. Sugar and ethanol concentrations were monitored by Ion Chromatography (Dionex ICS 3000 Thermo Scientific Waltham, MA, USA) and the optical density was measured at $\mathrm{OD}_{595 \mathrm{~nm}}$ using Thermo Scientific (Pittsburgh, PA) Evolution 605 UV/Vis Spectrophotometer to determine cell density during the course of fermentation.

\subsection{Analytical and Instrumentation Analyses}

2.5.1 Ion Chromatography (IC) Analysis: For the sugar analysis (glucose, xylose, arabinose, galactose, and mannose) were quantified against a fucose internal standard, polymeric sugar concentration was calculated from the concentration of the corresponding monomeric sugar, using an anhydro correction of 0.88 (or 132/150) for C-5 sugars (xylose and arabinose) and a correction of 0.90 (or 162/180) for C-6 sugar (glucose, galactose, and mannose). An Ion Chromatography System (Dionex ICS 3000 Thermo Scientific Waltham, MA, USA) with an electrochemical detector with a gold electrode, two guard columns (an Amino Trap Bio1C and a Carbo Pac PA1 (Dionex)) and a 4 x 250 mm Carbopac PA1 column (Dionex) maintained at 25

${ }^{\circ} \mathrm{C}$ was used. The eluents were $3 \mathrm{mM}$ sodium hydroxide, $300 \mathrm{mM}$ sodium hydroxide, and distilled water which were prepared with ultrapure water, partly degassed using vacuum and were run through the column at a flow rate of $1 \mathrm{~mL} \mathrm{~min}^{-1}$.

For the ethanol analysis a Dionex ICS 3000 with an electrochemical detector with a platinum electrode, and ion-pac ICE-AS1 guard column (Dionex) and a 4 x $250 \mathrm{~mm}$ Ion-Pac ICE-AS1 column (Dionex) maintained at $25^{\circ} \mathrm{C}$ was used. The eluent was $100 \mathrm{mM}$ methanesulfonic acid which was prepared with ultrapure water partly degassed using vacuum and was run through the column at a flow rate of $0.18 \mathrm{~mL} \mathrm{~min}^{-1}$.

2.5.2 Fiber length Analysis: The length of fibers was measured using MorFi apparatus (aBell Engineering, Hadley, NY) by computer analysis of images of the suspension flowing through a 
flat cell observed by a digital CCD video camera. Two grams of oven-dried PMS (original, acid washed, and fibers collected after enzymatic hydrolysis) was suspended in $500 \mathrm{~mL}$ distilled water and mixed rigorously with a magnetic stirrer for uniform distribution of fibers. Automated Morfi LB-01 analyzes the morphological properties of fibers (width, coarseness, kink and curl) and determines the arithmetical mean fiber length $(F L)$ using:

$F L=\frac{\sum z_{i} \cdot l_{i}}{\sum z_{i}}$

where $z_{i}$ is the number of fibers in a given batch of length and $l_{i}$ is the mean length of fibers in the given batch.

\subsection{Statistical Analysis}

Statistical analyses were carried out using a two-level factorial design $\left(2^{3}\right)($ DesignExpert ${ }^{\circledR}$ version 9.0.3.1, Stat-Ease, Inc. Minneapolis, MN). The order of significant effect of (from most to least significant) one chemical de-ashing, two cationic polymer additions, and three $\mathrm{H}_{2} \mathrm{O}_{2}$ pretreatment was chosen according to their rank and position above the $\mathrm{t}$-value and Bonferroni lines in the Pareto chart. Using the analysis of variance (ANOVA) in the Stat-Ease statistical program, the effects of the de-ashing, cationic polymer addition, and $\mathrm{H}_{2} \mathrm{O}_{2}$ pretreatment on enzymatic hydrolysis and fermentation associated performance parameters were evaluated. The sign (positive or negative) of the model coefficients, and p-values were used to describe the effect (positive or negative) and statistical significance of the various treatments and chemical additions. 


\section{Results and Discussion}

\subsection{De-ashing of Sludge by Chemical Pretreatment and Mechanical Fractionation}

The PMS samples were analyzed to determine solids, ash (at $575^{\circ} \mathrm{C}$ ) content based on oven-dry untreated PMS (Table 1). Sample A has the highest ash (55.3\% g ash / g oven dry sludge) content compared with the other PMS samples tested due primarily to fillers and other additives that become concentrated during the reprocessing for making recycled paper. Nikolov et al. (2000) reported that high ash content adheres to the fiber forming an adhesive envelope around the cellulose fibers, and is also responsible for the alkaline $\mathrm{pH}$ (7-10) of the PMS not optimal for enzyme, thus affecting enzymatic hydrolysis rate. From the various chemicals tested (such as $\mathrm{H}_{2} \mathrm{SO}_{4}, \mathrm{HCl}, \mathrm{CH}_{3} \mathrm{COOH}, \mathrm{HNO}_{3}, \mathrm{EDTA}, \mathrm{H}_{3} \mathrm{PO}_{4}$ ), hydrochloric acid is the most effective at removing ash (approximately $95 \%$ removal from the untreated PMS, (Cátia V. T. et al., 2012). Another study by Chen et al. (2014a) reported $82-98 \%$ ash removal by mechanical fractionation using a Pulmac Masterscreen.

In this study, two (A and B) out of four PMS samples tested were chemically washed with $\mathrm{HCl}$ overnight with stirring at room temperature. Three samples (A, B, and C) were processed with a two-stage ash removal process utilizing $0.223 \mathrm{~mm}$ diameter holes in the first stage and a wire mesh screen with openings of $0.075 \mathrm{~mm}$ in the second stage. The ash content of the PMS decreased significantly after chemical and mechanical removal (as shown in Table 1). The ash removal from the tested PMS with acid washing ranged from $65.8 \%$ to $76.7 \%$, while with mechanical removal from $70.1 \%$ to $88.9 \%$. These agree with previous results by Cátia V. T. et al. (2012) and Chen et al. (2014a) indicating that ash removal depends on type of PMS and the fillers/additives added during the paper making process. These results also show that mechanical removal was more effective in removing ash from the PMS compared to acid 
washing. However, each technique has its own advantages and disadvantages. Using $\mathrm{HCl}$ to remove $\mathrm{CaCO}_{3}$ has the disadvantage of producing unwanted compounds such as $\mathrm{CaCl}_{2}$ and $\mathrm{CO}_{2}$ as shown in Eq. (1). However, this problem could be tackled adopting new technologies for ions removal or replacing the waste stream by fresh water replacement (Shen et al., 2012). In addition, huge amounts of water are required to neutralize the $\mathrm{pH}$ of the fibers after acid wash, but fresh water could be easily replaced by condensate stream from evaporation units after distillation in the scaling up the de-ashing process (Alkasrawi et al., 2013). On the other hand, use of two screens $(0.223-\mathrm{mm}$ and $0.075-\mathrm{mm})$ in mechanical fractionation has the risk of losing the fine fibers that pass through second stage screen (10 to $25 \%$ from the mass balance calculations, data not shown). Thus the choice of de-ashing method depends on the type of paper PMS, operational ease and additional processing steps required to recover pure cellulose fibers. The advantage of both techniques is that removal of ash increased the total carbohydrate content of the PMS after acid wash up to $20 \%$ (g total sugar / g oven dry PMS) (Duncan et al., 2015), and up to $35-45 \%$ (g total sugar / g oven dry PMS) after mechanical fractionation (Table 2). An increase in carbohydrate composition after de-ashing has also been reported by previous studies Cátia V. T. et al. (2012) (de-ashing of kraft paper PMS by chemical pretreatment) and Chen et al. (2014a) (de-ashing of both virgin kraft and recycled de-inking paper PMS by mechanical fractionation). The increase in carbohydrate composition by chemical and mechanical fractionation of paper sludge lowers the total inlet flow into the hydrolysis process and reduces the reactor sizes needed. Additionally, it improves saccharification efficiency by removing a high portion of ash and impurities that can hinder the enzymatic hydrolysis and fermentation. De-ashing provides an increased surface area for cellulases to bind onto the substrate, which was limited due to the presence of mineral fillers. Thus, sugar concentration in 
the fermentation unit will be higher and higher ethanol concentration will be produced, reducing energy demand for distillation. Thus enhancement in enzyme digestibility, fermentation efficiency, and final ethanol concentration by de-ashing, leads to improvements in the overall process economics.

\subsection{Effect of c-PAM and $\mathrm{H}_{2} \mathrm{O}_{2}$ Pretreatment on Enzymatic Hydrolysis}

Untreated and chemical de-ashed (with $\mathrm{HCl}$ ) PMS samples were subjected to enzymatic hydrolysis with the addition of two cationic polyelectrolytes, XP 10016 (XP-16) and XP 10020 (XP-20), and $\mathrm{H}_{2} \mathrm{O}_{2}$ impregnation. The influence of c-PAM XP-16 \& XP-20 additions, and $\mathrm{H}_{2} \mathrm{O}_{2}$ treatment on the cellulose conversion during enzymatic hydrolysis with a dosage of $3.4 \%$ (g enzyme / g cellulose) using untreated and chemical de-ashed PMS (B) is shown in Fig. 1. For the unwashed PMS, the commercial second-generation enzyme cocktail produced $1.8 \mathrm{~g} / \mathrm{L}$, which corresponds to $14.9 \%$ (g glucose / g cellulose) maximum cellulose conversion at the slowest rate of $0.05 \mathrm{~g}$ glucose $/ \mathrm{L} / \mathrm{h}$ (Table 3), which is as expected due to the high ash content. Addition of cationic polyelectrolytes XP-16 and XP-20 resulted in slight increases in glucose yields; 25.2 and $27.6 \%$ (g glucose / g cellulose), respectively. This slight improvement in glucose yields with the addition of cationic polyelectrolytes can be attributed to the proposed patching mechanism (Mora et al., 2011) promoting the binding of cellulase to accessible cellulose fiber. Further improvement in enzyme performance up to $40 \%$ (g glucose/ $\mathrm{g}$ cellulose) cellulose conversion at a slower rate $0.15 \mathrm{~g}$ glucose $/ \mathrm{L} / \mathrm{h}$ ) was observed when the unwashed PMS was impregnated with $\mathrm{H}_{2} \mathrm{O}_{2}$ prior to hydrolysis. This suggests that dissolution of lignin, ash and other impurities of the PMS by oxidative pretreatment at room temperature helped the enzyme to access cellulose fiber. Currently no studies have reported utilizing $\mathrm{H}_{2} \mathrm{O}_{2}$ in the pretreatment of paper mill sludge although it is used in the paper bleaching process. However, several studied showed 
impregnation of lignocellulosic feedstock with $\mathrm{H}_{2} \mathrm{O}_{2}$ prior to hydrolysis considerably improved the enzymatic hydrolysis (Cao et al., 2012).

Removing $65.8 \%$ of ash from the PMS using chemical de-ashing increased the rate $(0.82$ g glucose/L/h) and percentage of glucose yield (75.6\% g glucose/ g cellulose) dramatically (Table 3), suggesting an increase in accessibility of cellulose to the cellulase enzyme. Interestingly, the fiber length of the PMS increased after the $\mathrm{HCl}$ treatment, suggesting the uncoiling of fibers with the removal of ash (Table 1). The increase in accessibility of the treated fiber was seen by a reduction of fiber length $(156 \mu \mathrm{m})$ when compared with the fiber length of untreated PMS (484 um) after 72 hours enzyme hydrolysis (Table 1). Removal of ash also resulted in an increasing percentage of fines produced that can be directly correlated to enzyme action and increased hydrolysis yields (Table 3). Reye et al. (2009) reported similar reduction in fiber length and increases in percentage of fines during the hydrolysis of bleached hardwood pulp fiber to glucose with mixed cellulases (Optimase CX and Pergalase 7547) at relatively negligible ash content. The two cationic polyelectrolytes tested (both XP-16 and XP-20) improved hydrolysis yield by $16 \%$ (g glucose / g cellulose) (Table 3). Our results are in agreement with the study by Reye et al. (2011) who reported similar improvement in enzymatic hydrolysis of bleached softwood Kraft pulp by approximately 10-20 \% (g glucose / g cellulose) glucose yield using a wide variety of c-PAM from XP10025 to XP 10033 with different cationicity and molecular weight. The observed increase in hydrolysis rates and glucose yields may be due to the charge neutralization of fiber (negative zeta potential) with the addition of cationic polyelectrolyte, thus promoting the binding of enzyme (negative zeta potential) to the cellulose fiber. Impregnation with hydrogen peroxide increased cellulose conversion up to $99 \%$ (g glucose / $\mathrm{g}$ cellulose) of the maximum yield, and rates of $2.0 \mathrm{~g}$ glucose $/ \mathrm{L} / \mathrm{h}$ were observed. 
The increase in rate and sugar yield with hydrogen peroxide could be due to the dissolution of lignin. Studies have shown dissolution of over $85 \%$ of lignin when rice straw was treated with $1.0 \%(\mathrm{w} / \mathrm{v})$ hydrogen peroxide at $45^{\circ} \mathrm{C}$ for $12 \mathrm{~h}$ (Sun et al., 2001). The improvement in hydrolysis yield observed in our study after dissolution of lignin by $\mathrm{H}_{2} \mathrm{O}_{2}$ agrees with a previous study by Tan et al. (2009) who reported that $93.6 \%$ of cellulose in bagasse treated with hydrogen peroxide was hydrolyzed by cellulase enzymes. Zhao et al. (2007) found that $82.5 \%$ biomass was converted to sugars after sugarcane bagasse was treated with peracetic acid (a hydrogen peroxide related compound).

The hierarchy of different treatments (chemical de-ashing, c-PAM addition, and $\mathrm{H}_{2} \mathrm{O}_{2}$ pretreatment) was analyzed by the two-level factorial design (Table 4). A positive coefficient was calculated for each treatment relating to higher glucose concentrations and faster rate indicators after each treatment and negative coefficients represents slight or minimal effect on enzymatic hydrolysis performance $(\mathrm{p}<0.01$, Table 4$)$. From the analysis we found that $\mathrm{HCl}$ washing for removing ash content from the sludge provided the largest impact on improving the enzymatic hydrolysis yields and rates observed in Fig.1 and Table 3. Addition of cationic polyelectrolytes and $\mathrm{H}_{2} \mathrm{O}_{2}$ pretreatments had a positive effect after removing ash from the sludge as discussed above and low negative coefficient values for the interaction effect of these treatments (Table 4).

In summary, for higher glucose concentrations and faster hydrolysis rates, fillers and other additives that surround the cellulose fibers need to be removed by either chemical pretreatment or mechanical fractionation. After removal of the adhesive barrier, hydrogen peroxide impregnation at room temperature showed almost $99.5 \%$ (g glucose / g cellulose) 
maximum cellulose conversion at higher rates and achieved maximum yields within 48 hours of hydrolysis.

The optimization of enzymatic hydrolysis requires intensive and laborious work in order to find the optimal operating conditions. However, enzymatic hydrolysis operation parameters for optimal yield have been clearly identified as feedback inhibition, substrate crystallinity and presence of inhibitors (Zhang et al., 2009). The de-ashed PMS does not contain any inhibitory chemicals that affect enzyme binding to the cellulosic fiber, which has a degree of crystallinity that affects binding as well. The major concern is the substrate feedback inhibition. Therefore, in this research we constructed mathematical modeling to describe the overall conversion rate with emphases on substrate inhibition.

\subsection{Mathematical modeling of glucose production rate}

For the hydrolysis batch process considered in this study, the conservation of mass of glucose can be described as:

$$
\frac{d C}{d t}=r_{G}
$$

Where $C$ is the glucose concentration in $\mathrm{g} / \mathrm{L}, r_{G}$ is the production rate of glucose in $\mathrm{g} /(\mathrm{L} . \mathrm{h})$ and $t$ is the hydrolysis time in $\mathrm{h}$. Using a pseudo first-order model, in which the production rate is directly proportional to the concentration difference at equilibrium and at time $t$, of the form $r_{G}=$ $k\left(C_{e}-C\right)$, Eq. (4) becomes:

$$
\frac{d C}{d t}=k\left(C_{e}-C\right)
$$

where $k$ is the apparent pseudo first-order rate constant in $\mathrm{h}^{-1}$ and $C_{\mathrm{e}}$ is the equilibrium concentration. Applying the boundary condition $C(t=\infty)=C_{e}$ after integrating Eq. (5) gives: 


$$
C(t)=C_{\mathrm{e}}-C_{\mathrm{e}} \mathrm{e}^{-k t}
$$

Eq. (6) can be rewritten in a linearized form as:

$$
\ln \left[C_{\mathrm{e}}-C(t)\right]=\ln C_{\mathrm{e}}-k t
$$

In order to verify the validly of such model, the experimental data shown in Fig. 1 were used where $\ln (\mathrm{Ce}-\mathrm{C})$ was plotted against hydrolysis time, $\mathrm{t}$, for each $\mathrm{HCl}$ treated/untreated cases; see Fig. 2. Qualitatively, the experimental data are fairly close to the corresponding linear trends. Quantitatively, the fit of the pseudo first-order model was measured in terms of the correlation coefficient $\left(\mathrm{R}^{2}\right)$. The $\mathrm{R}^{2}$ given in Table 5 are in the range $0.9202-0.9889$, i.e. they are closed to unity. This confirms that the production rate of glucose can be modeled adequately using pseudo first-order kinetics. Note that the slope of the linear plot is the $-\mathrm{k}$ and the intercept is the $\ln C_{e}$; see Eq. (7). Table 5 demonstrates that the value of apparent kinetic parameter, $k$, varies from 0.0477 (untreated-control case) to $0.0747(\mathrm{HCl}$ treated-XP2). The kinetic parameter, $k$, can be approximated by a mean value of $0.0660 \mathrm{~h}^{-1}$ which can be used to design large-scale continuous hydrolysis processes. Furthermore, we found that the equilibrium concentrations illustrated in Table 5 are in excellent agreement with the corresponding experimental concentrations measured after $72 \mathrm{~h}$.

\subsection{Effect of solids loading on enzymatic hydrolysis of paper sludge}

Fig. 3 shows the time course of glucose concentration obtained during enzymatic hydrolysis of different paper sludge at four different solids loading $2.5 \%, 5 \%, 10 \%$, and $20 \%$ (w/v) conducted in $500 \mathrm{~mL}$ Erlenmeyer flasks at a constant enzyme loading of $3.4 \%$ (g enzyme/g cellulose). Increasing solids loading resulted in a linear increase in glucose concentration because of the higher initial cellulose content with respect to total solids added. However, the duration of achieving maximum sugar concentration was increased from 24 h to 72 
$\mathrm{h}$ with increased solids loading from 2.5 to $20 \%$ (w/v), respectively. Fig. 4 shows the final glucose concentration at the different solids loading $(2.5 \%, 5 \%, 10 \%$, and $20 \% \mathrm{w} / \mathrm{v})$ of four PMS samples tested for the optimization studies. The glucose concentration increased with respect to solids loading, however at $20 \%$ (w/v) solids loading the final concentration of 51-77 $\mathrm{g} / \mathrm{L}$ is only 55-68 \% (g glucose / $\mathrm{g}$ cellulose) of maximum sugars achievable. The decrease in glucose yield is likely due to the rheological challenges at high solids loading of $20 \%(\mathrm{w} / \mathrm{v})$ that has been commonly observed in other studies (Roche et al., 2009). Other possible explanations for this observation include: insufficient mixing, (Roche et al., 2009) product inhibition as a result of increasing sugar concentration, decreased water availability, irreversible binding of the enzyme to the substrate, including non-productive binding to lignin, inhibition of enzyme adsorption, and enzyme denaturation (Yu et al., 2012). Insufficient mixing of high viscosity solution with increased solids loading cause improper mass transfer with reduced availability of water with paper sludge (which has higher propensity in adsorbing the water than original lignocellulosic feedstock). Methods to overcome these complications and the reasons for decreased cellulose conversion with respect to high solids loading need further investigation. The hydrolysis results observed this study are comparable to other previous reported studies conducted at high solids loading, performed with specially designed reactors for handling high solids of different lignocellulosic biomass. Recently, Puri et al. (2013) showed maximum cellulose conversion of only $68 \%$ ( $g$ glucose / g cellulose) during the enzymatic hydrolysis of pulp derived from municipal solid waste in a fed batch single-stage reactor at $20 \%(\mathrm{w} / \mathrm{v})$ total solids content. Di Risio et al. (2011) showed only $71 \mathrm{~g} / \mathrm{L}$ of glucose could be obtained when pretreated poplar was hydrolyzed at $20 \%(\mathrm{w} / \mathrm{v})$ dry solids loading using a combination of enzyme cocktails in shake flasks. Cara et al. (2007) conducted enzymatic hydrolysis on 
pretreated olive tree pruning biomass and achieved a maximum glucose concentration of 64.5 $\mathrm{g} / \mathrm{L}$ at $20 \%(\mathrm{w} / \mathrm{v})$ solids loading in normal shake flasks. Another study showed that a novel laboratory scale roller bottle reactors (RBRs) produced $16 \%$ higher glucose concentration than conventional shake flask reactors for hydrolyzing pretreated corn stover at $20 \%(\mathrm{w} / \mathrm{v})$ solids loading (Roche et al., 2009). Zhang et al. (2009) showed the feasibility of using a peg mixer, commonly used in the pulp and paper industry, for high solids enzymatic hydrolysis at $20 \%$ (w/v) solids loading. Use of a peg mixer resulted in $158 \mathrm{~g} / \mathrm{L}$ of glucose from organosolv pretreated poplar with an $85 \%$ glucose yield during enzymatic hydrolysis at $20 \%$ (w/v) solids loading. Jorgensen et al. (2007) showed that hydrolyzing pretreated wheat straw in a five chambered liquefaction reactor achieved 76 and $86 \mathrm{~g}$ of glucose per $\mathrm{kg}$ of enzymatic hydrolyzate at $20 \%(\mathrm{w} / \mathrm{v})$ and $40 \%(\mathrm{w} / \mathrm{v})$ solids loading, respectively. Thus these studies confirm that a specially designed reactor is required to achieve higher final sugar concentrations and higher glucose yields for the hydrolysis of biomass or paper sludge at high solids loading. From Fig. 3 and $4,10 \%(\mathrm{w} / \mathrm{v})$ solids loading is considered to be optimum for the paper sludge under tested condition and hydrolyzate for fermentation experiments were obtained using this solids loading. However, increasing the solid loading in enzymatic hydrolysis step in PMS conversion to ethanol is an economical process step. Since enzymatic loading and simultaneous saccharification and fermentation (SSF) plays crucial roles in process economy (Alkasrawi et al., 2006), further enzymatic hydrolysis experiments using fed batch method and SSF utilizing paper sludge at high solids loading are currently under study.

\subsection{Effect of c-PAM and $\mathrm{H}_{2} \mathrm{O}_{2}$ Pretreatment on Fermentation:}

Fig. 5 shows the general time course profile of glucose consumption, ethanol production, and optical cell density representing the effect of cationic polyelectrolytes (XP-16 and XP-20) 
and $\mathrm{H}_{2} \mathrm{O}_{2}$ pretreatment during the fermentation by industrial yeast strain FermPro using the enzymatic hydrolyzate obtained by saccharification of chemical de-ashed sludge A at optimal 10 $\%(\mathrm{w} / \mathrm{w})$ solids loading (as discussed in the previous section). The associated performance parameters (ethanol yields, final ethanol concentrations, and rates of glucose consumption, and ethanol productivities) are summarized in Table 6. Although the glucose concentration in the enzymatic hydrolyzate was higher (for example $70.5 \mathrm{~g} / \mathrm{L}$ in $\mathrm{H}_{2} \mathrm{O}_{2}$ pretreated sludge hydrolysis), the addition of yeast fermentation and nutrient medium diluted the glucose concentration (to 64.3 $\mathrm{g} / \mathrm{L}$ ) at the start of fermentations (first two data points of glucose consumption curve in Fig. 5). Fermentation of $\mathrm{HCl}$ washed enzymatic hydrolyzate (with no c-PAM addition and $\mathrm{H}_{2} \mathrm{O}_{2}$ pretreatment) produced ethanol and consumed sugars much faster ( $<9$ hrs.) than the XP-16, XP20, and $\mathrm{H}_{2} \mathrm{O}_{2}$ pretreated hydrolyzate with relatively higher rate of glucose consumption and theoretical maximum ethanol yields $(5.4 \mathrm{~g}$ glucose $/ \mathrm{L} / \mathrm{h}$ and $0.5 \mathrm{~g}$ ethanol / g glucose, respectively Table 6). While $\mathrm{H}_{2} \mathrm{O}_{2}$ pretreatment showed the most promising for improving enzymatic hydrolysis performance with higher glucose yield and rate of glucose production, during the fermentation it was shown to decrease the rate of glucose consumption and ethanol titers. One possible explanation may be due to the disinfectant effect of hydrogen peroxide on yeast cells which was studied by Semchyshyn (2014) who reported that hydrogen peroxide is highly toxic to yeast, inhibiting or entirely stopping the yeast growth and fermentation when added under aerated condition. However, in the same study it was showed that without the aeration the effect of hydrogen peroxide on yeast cells is diminished. In another study showed that Saccharomyces cerevisiae was sensitive towards the presence of hydrogen peroxide, which caused depletion of intracellular glutathione that plays an important role in the adaptive response of the yeast to oxidative damage (Zubko \& Zubko, 2013). The cell growth (inside chart of Fig. 5) and glucose 
consumption profiles clearly shows the inhibition effect of hydrogen peroxide on the industrial yeast FermPro. Our yeast took almost 15 hours to overcome the inhibition effect under anaerobic conditions, producing higher cell density at a slower rate. The higher initial glucose concentration apparently produced more yeast biomass at the expense of ethanol production. Addition of cationic polymer XP-16 during the enzymatic hydrolysis delayed the yeast fermentation, taking 12 hours for complete consumption of glucose. The rate of glucose consumption, ethanol yield, productivity and titers are slightly higher when compared to the fermentation of hydrogen peroxide pretreated hydrolyzate (Table 6). From the tested conditions, fermentation of hydrolyzate with XP-20 showed the highest rate of glucose consumption (5.69 $\mathrm{g}$ glucose/L/h), ethanol yield $(0.48 \mathrm{~g}$ ethanol / $\mathrm{g}$ glucose which is $95 \%$ of maximum theoretical yields), ethanol productivity $(2.81 \mathrm{~g}$ ethanol produced/L/h), and ethanol titers $(28.1 \mathrm{~g} / \mathrm{L}$ final ethanol concentration). A possible explanation for the observed difference in fermentation results with c-PAM XP-16 and XP-20 is the intrinsic difference of each polyelectrolyte. XP-20 is a low molecular weight polyelectrolyte and has high cationicity (100\%) compared to XP-16 (which is high molecular weight with low cationicity $30 \%$ ). The high cationicity and easily miscible characteristic of XP-20 could have assisted in uptake of glucose faster than XP-16 (creating viscous fermentation broth due to the high molecular weight: visual observation) and thus higher productivity and achieving the maximum concentration of ethanol within 9 hours of fermentation.

Similar performance trends were observed during the fermentation of the other three PMS samples (de-ashed sludge B, sludge C and sludge D). XP-20 showed better ethanol production than the addition of c-PAM XP-16 and $\mathrm{H}_{2} \mathrm{O}_{2}$ pretreatment conditions tested during the enzymatic hydrolysis, with higher final ethanol concentration (25-30 g/L) and higher ethanol 
yields up to $95 \%$ of maximum theoretical ethanol yield ( $0.51 \mathrm{~g}$ ethanol / g glucose), with the remaining $5 \%$ of the sugar consumed by the yeast for cellular maintenance, thus making $100 \%$ complete utilization of glucose. Our results are comparable with the fermentation profiles of an industrially adapted yeast Saccharomyces cerevisiae $\mathrm{D}_{5} \mathrm{~A}$ strain utilizing de-ashed and fractionated paper sludge hydrolyzate in separate hydrolysis and fermentation studies (SHF) (Cao et al., 2012). However, the final ethanol concentration achieved in this study at the best conditions for fermentation is still lower than the economically feasible concentrations ( $76.5 \mathrm{~g} / \mathrm{L}$ : (Öhgren et al., 2006)). To achieve such ethanol titers requires higher initial sugar concentration $\geq$ $150 \mathrm{~g} / \mathrm{L}$, which is equivalent to initial paper sludge solids loading (approximately $20 \% \mathrm{w} / \mathrm{v}$ ) during the enzymatic hydrolysis. However, an economic evaluation study completed by Schniderman et al., 2015 showed that evaporation prior to fermentation resulted in higher energy demand due to the high latent heat of water while the use of expensive reverse osmosis membrane accounts for up to $15 \%$ of the overall bio-refinery process cost and remains as a barrier for the commercial application (Gurram \& Menkhaus, 2013). These complications further emphasize the importance of high solids loading research which we are currently investigating for an economical bioethanol conversion from paper sludge process as envisioned in Fig. 6 .

\section{Conclusions}

We found that PMS de-ashing can greatly improve the enzymatic hydrolysis performance by increasing the surface area available for enzymatic binding. We found also addition of cationic polymers (accelerants) and $\mathrm{H}_{2} \mathrm{O}_{2}$ pretreatment further increasing the affinity and activity of enzyme substrate interaction. Fermentation of the enzymatic hydrolyzate obtained at $10 \%$ solids loading and with accelerant addition produced high titers of ethanol (95\% of theoretical ethanol 
yields) at a faster rate. A combination of de-ashing of PMS, addition of accelerant, or $\mathrm{H}_{2} \mathrm{O}_{2}$

pretreatments has the potential to greatly reduce the costs within the lignocellulosic biochemical transformation process.

\section{Acknowledgments}

The work was funded in a part by an Economic Development Incentive Grant (131-5-909511)

from the University of Wisconsin System, Madison, WI, USA. In addition, the Wisconsin Institute for Sustainable Technology receives funding support from the U.S. Department of Agriculture National Institute of Food and Agriculture. The authors are grateful to all the staff at the four mills for providing sludge samples and information regarding the filler and additives used in the paper making process. Authors acknowledge Sophie Demchik and Justin Hall for technical assistance. 


\section{References}

1. Alkasrawi, M., Abu Jrai, A., Al-Muhtaseb, A.H. 2013. Simultaneous saccharification and fermentation process for ethanol production from steam-pretreated softwood: Recirculation of condensate streams. Chem Eng J. 225:574-579.

2. Alkasrawi, M., Rudolf, A., Lidén, G., Zacchi, G. 2006. Influence of strain and cultivation procedure on the performance of simultaneous saccharification and fermentation of steam pretreated spruce. Enzy Microb Tech. 38: 279-286.

3. Cao, W., Sun, C., Liu, R., Yin, R., Wu, X. 2012. Comparison of the effects of five pretreatment methods on enhancing the enzymatic digestibility and ethanol production from sweet sorghum bagasse. Biores Tech. 111: 215-221.

4. Cara, C., Moya, M., Ballesteros, I., Negro, M.J., González, A., Ruiz, E. 2007. Influence of solid loading on enzymatic hydrolysis of steam exploded or liquid hot water pretreated olive tree biomass. Proc Biochem. 42: 1003-1009.

5. Cátia V. T., M., Jorge M. S., R., M. Graça V. S., C. 2012. Primary sludge from pulp and paper mills as a potential raw-material to produce value-added products. The 45 th ABTCP International Pulp and Paper Congress and VII IberoAmerican Congress on Pulp and Paper Research. October, 9-11, Sao Paulo Brazil.

6. Chen, H., Han, Q., Daniel, K., Venditti, R., Jameel, H. 2014a. Conversion of industrial paper sludge to ethanol: fractionation of sludge and its impact. Appl Biochem Biotechnol. 174: 2096-113.

7. Chen, H., Venditti, R., Gonzalez, R., Phillips, R., Jameel, H., Park, S. 2014b. Economic evaluation of the conversion of industrial paper sludge to ethanol. Ener Econ. 44 281290.

8. Cooper, D., Erickson, J. Agenda 2020: A technology vision and research agenda for America's forest, wood, and paper industry. American Forest \& Paper Association. 1994.

9. Correia, J.A.d.C., Júnior, J.E.M., Gonçalves, L.R.B., Rocha, M.V.P. 2013. Alkaline hydrogen peroxide pretreatment of cashew apple bagasse for ethanol production: Study of parameters. Biores Technol. 139: 249-256.

10. Di Risio, S., Hu, C.S., Saville, B.A., Liao, D., Lortie, J. 2011. Large-scale, high-solids enzymatic hydrolysis of steam-exploded poplar. Biofue Biopro Bioref. 5: 609-620.

11. Duncan, S.M., Gurram, R.N., Gorzek, B.R., Lecher, N.J., Alkasrawi, M., Singsaas, E. 2015. Pulp and paper mill sludge as a source of sugars for use in the production of renewable chemicals and fuels. TAPPI J. Manuscript submitted for publication.

12. Gurram, R.N., Menkhaus, T.J. 2013. Analysis and Characterization of Heat Transfer Fouling during Evaporation of a Lignocellulosic Biomass Process Stream. Ind Eng Chem Res. 52: 11111-11121.

13. Haynes, R.D., Banerjee, S., Mora, S. 2013. Application of enzyme accelerant technology for cellulosic sludge in pulp and paper mills. J-FOR. 3: 42-49.

14. Ioelovich, M. 2014. Waste paper as promising feedstock for production of biofuel. J Sci Res Rep. 3: 905-916.

15. Jorgensen, H., Vibe-Pedersen, J., Larsen, J., Felby, C. 2007. Liquefaction of lignocellulose at high-solids concentrations. Biotechnol Bioeng. 96: 862-70.

16. Kang, L., Wang, W., Pallapolu, V., Lee, Y. 2011. Enhanced ethanol production from deashed paper sludge by simultaneous saccharification and fermentation and simultaneous saccharification and co-fermentation. BioRes. 6: 3791-3808. 
17. Machani, M., Nourelfath, M., D'Amours, S. 2014. A mathematically-based framework for evaluating the technical and economic potential of integrating bioenergy production within pulp and paper mills. Bioma Bioener. 63: 126-139.

18. Mora, S., Lu, J., Banerjee, S. 2011. Mechanism of rate enhancement of wood fiber saccharification by cationic polyelectrolytes. Biotechnol Lett. 33: 1805-8.

19. Nikolov, T., Bakalova, N., Petrova, S., Benadova, R., Spasov, S., Kolev, D. 2000. An effective method for bioconversion of delignified waste-cellulose fibers from the paper industry with a cellulase complex. Biores Technol. 71: 1-4.

20. Öhgren, K., Rudolf, A., Galbe, M., Zacchi, G. 2006. Fuel ethanol production from steampretreated corn stover using SSF at higher dry matter content. Bioma Bioener. 30: 863869.

21. Puri, D.J., Heaven, S., Banks, C.J. 2013. Improving the performance of enzymes in hydrolysis of high solids paper pulp derived from MSW. Biotech Biofuel. 6: 107-107.

22. Reye, J.T., Lu, J., Maxwell, K.E., Banerjee, S. 2011. Enhancement of cellulase catalysis of wood pulp fiber by cationic polyelectrolytes. Bioma Bioener. 35: 4887-4891.

23. Reye, J.T., Maxwell, K., Rao, S., Lu, J., Banerjee, S. 2009. Cationic polyacrylamides enhance rates of starch and cellulose saccharification. Biotechnol Lett. 31: 1613-6.

24. Roche, C., Dibble, C., Stickel, J. 2009. Laboratory-scale method for enzymatic saccharification of lignocellulosic biomass at high-solids loadings. Biotech Biofue. 2: 111.

25. Schniderman, S.J., Gurram, R.N., Menkhaus, T.J., Gilcrease, P.C. 2015. Economic analysis of biomass-to-biofuel conversion: an alternative approach with higher sugar concentration and cell recycle prior to fermentation. Biotech Prog. In Press.

26. Semchyshyn, H.M. 2014. Hormetic concentrations of hydrogen peroxide but not ethanol induce cross-adaptation to different stresses in budding yeast. Inter J microbio. 2014.

27. Shen, M., Li, B., Yu, J. 2012. Investigation on electrochemical removal of $\mathrm{CaCl}_{2}$ from LiCl-KCl melts. Electrochimica Acta. 62: 153-157.

28. Sluiter, J.B., Ruiz, R.O., Scarlata, C.J., Sluiter, A.D., Templeton, D.W. 2010. Compositional analysis of lignocellulosic feedstocks. 1. Review and description of methods. J Agric Food Chem. 58: 9043-53.

29. Sun, R., Tomkinson, J., Mao, F.C., Sun, X.F. 2001. Physicochemical characterization of lignins from rice straw by hydrogen peroxide treatment. J App Poly Sci. 79: 719-732.

30. Tan, H., Yang, R., Sun, W., Wang, S. 2009. Peroxide-Acetic Acid Pretreatment To Remove Bagasse Lignin Prior to Enzymatic Hydrolysis. Ind Eng Chem Res. 49: 14731479.

31. Wingren, A., Galbe, M., Zacchi, G. 2003. Techno-economic evaluation of producing ethanol from softwood: comparison of SSF and SHF and identification of bottlenecks. Biotech Prog. 19: 1109-17.

32. Yu, Z., Jameel, H., Chang, H.-m., Philips, R., Park, S. 2012. Evaluation of the factors affecting avicel reactivity using multi-stage enzymatic hydrolysis. Biotech Bioeng. 109: 1131-1139.

33. Zhang, X., Qin, W., Paice, M.G., Saddler, J.N. 2009. High consistency enzymatic hydrolysis of hardwood substrates. Biores Tech. 100: 5890-5897.

34. Zhao, X.-b., Wang, L., Liu, D.-h. 2007. Effect of several factors on peracetic acid pretreatment of sugarcane bagasse for enzymatic hydrolysis. J Chem Tech Biotech. 82: 1115-1121. 
35. Zubko, E., Zubko, M. 2013. Co-operative inhibitory effects of hydrogen peroxide and iodine against bacterial and yeast species. BMC Res Notes. 6: 272. 


\section{Figure Captions}

Figure 1. Influence of c-PAM addition, and $\mathrm{H}_{2} \mathrm{O}_{2}$ pretreatment on enzymatic hydrolysis with untreated and chemical de-ashed sludge $\mathrm{B}$ at $3.4 \%$ enzyme dosage ( $\mathrm{g}$ enzyme / $\mathrm{g}$ cellulose). Error bars with less than 5\% standard deviation and smaller than symbols are not shown.

Figure 2. Linearized pseudo first-order model for production rate of glucose through enzymatic hydrolysis.

Figure 3. Effect of solids loading (SL) on enzymatic hydrolysis performance of paper sludge (glucose production during the course of hydrolysis). Error bars with less than 5\% standard deviation and smaller than symbols are not shown.

Figure 4. Enzymatic hydrolysis of sludge tested at different solids loading $(2.5 \%, 5 \%, 10 \%$, and $20 \%$ ) with $3.4 \%$ enzyme dosage ( $\mathrm{g}$ enzyme/g cellulose).

Figure 5. Influence of c-PAM addition and $\mathrm{H}_{2} \mathrm{O}_{2}$ pretreatment on fermentation (glucose consumption, ethanol production and optical density) with chemical de-ashed sludge $\mathrm{A}$ at $37^{\circ} \mathrm{C}$. Optical density is shown on inserted graph. Error bars with less than 5\% standard deviation and smaller than symbols are not shown.

Figure 6. Paper mill sludge to bioethanol process flow diagram. 
Table 1. Paper sludge origins, composition, ash removal efficiency and fiber length using chemical de-ashing and mechanical fractionation. A, B, C, and D: original sludge collected from paper mill. A2 and B2: Chemical pretreatment by hydrochloric acid. A3, B3, and C3: Mechanical fractionation by Pulmac MasterScreen (Secondary fiber rejects).

\begin{tabular}{|c|c|c|c|c|c|c|c|}
\hline \multicolumn{2}{|r|}{ Origin } & \multicolumn{4}{|c|}{$\begin{array}{c}\text { Content, } \% \text { w/w } \\
\text { (dry weight basis) }\end{array}$} & \multicolumn{2}{|c|}{ Fiber Length $(\mu \mathrm{m})$} \\
\hline $\begin{array}{l}\text { Sludge } \\
\text { ID }\end{array}$ & Paper Making Process & $\begin{array}{c}\text { Dry Matter } \\
(\%)\end{array}$ & $\operatorname{Ash}(\%)$ & $\begin{array}{c}\text { Fiber } \\
(\%)\end{array}$ & $\begin{array}{c}\text { Ash Removal } \\
(\%)\end{array}$ & $\begin{array}{c}\text { Before } \\
\text { Hydrolysis }\end{array}$ & $\begin{array}{c}\text { After } \\
\text { Hydrolysis }\end{array}$ \\
\hline $\mathbf{A}$ & $\begin{array}{l}\text { Kraft pulp and recycled } \\
\text { paper mill }\end{array}$ & 54.5 & 55.3 & 44.7 & 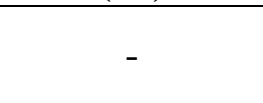 & 674 & 580 \\
\hline A2 & & 31.9 & 12.9 & 87.1 & 76.7 & 944 & 120 \\
\hline A3 & & 25.8 & 6.1 & 93.9 & 88.9 & 765 & 102 \\
\hline B & Kraft pulp and paper mill & 26.4 & 32.2 & 67.8 & - & 619 & 484 \\
\hline B2 & & 24.7 & 11.0 & 89.0 & 65.8 & 960 & 156 \\
\hline B3 & & 28.3 & 8.8 & 91.2 & 72.7 & 755 & 118 \\
\hline $\mathbf{C}$ & Kraft pulp and paper mill & 36.8 & 33.4 & 66.6 & - & 1078 & 195 \\
\hline C3 & & 25.9 & 10.0 & 90.0 & 70.1 & 797 & 123 \\
\hline D & Sulfite pulp specialty fibers & 24.8 & 1.1 & 98.9 & - & 1545 & 225 \\
\hline
\end{tabular}


Table 2. Composition of original, chemical de-ashing, and mechanical fractionated sludge. A, B, C, and D: original sludge collected from paper mill. A2 and B2: Chemical de-ashing by hydrochloric acid. A3, B3, and C3: Mechanical fractionation by Pulmac MasterScreen (Secondary fiber rejects).

\begin{tabular}{cccccccc}
\hline & \multicolumn{7}{c}{ Constituent (\% dry weight) } \\
\hline Sludge & $\begin{array}{c}\text { Lignin } \\
(\boldsymbol{\%})\end{array}$ & $\begin{array}{c}\text { Glucan } \\
(\boldsymbol{\%})\end{array}$ & $\begin{array}{c}\text { Xylan } \\
(\boldsymbol{\%})\end{array}$ & $\begin{array}{c}\text { Mannan } \\
(\boldsymbol{\%})\end{array}$ & $\begin{array}{c}\text { Arabanan } \\
(\boldsymbol{\%})\end{array}$ & $\begin{array}{c}\text { Galactan } \\
(\boldsymbol{\%})\end{array}$ & $\begin{array}{c}\text { Total sugars } \\
(\boldsymbol{\%})\end{array}$ \\
\hline $\mathbf{A}$ & 7.6 & 40.9 & 10.3 & 2.0 & 0.3 & 0.9 & 54.5 \\
$\mathbf{A 2}$ & 10.3 & 55.7 & 14.0 & 2.8 & 0.5 & 1.2 & 74.2 \\
$\mathbf{A 3}$ & 1.2 & 75.5 & 17.2 & 3.2 & 0.7 & 1.9 & 98.5 \\
$\mathbf{B}$ & 21.3 & 40.9 & 7.7 & 1.9 & 0.1 & 1.8 & 52.4 \\
$\mathbf{B 2}$ & 25.2 & 48.2 & 9.0 & 2.3 & 0.1 & 2.1 & 61.8 \\
$\mathbf{B 3}$ & 10.6 & 69.8 & 11.7 & 3.8 & 0.3 & 2.9 & 87.5 \\
$\mathbf{C}$ & 19.2 & 34.3 & 5.0 & 1.9 & 0.2 & 1.3 & 42.7 \\
$\mathbf{C 3}$ & 9.4 & 72.2 & 10.1 & 2.6 & 0.4 & 2.6 & 87.9 \\
$\mathbf{D}$ & 26.0 & 68.1 & 1.2 & 0.0 & 0.0 & 9.2 & 78.5 \\
\hline
\end{tabular}


Table 3. Influence of c-PAM (XP-16 and XP-20) addition and $\mathrm{H}_{2} \mathrm{O}_{2}$ pretreatment on cellulose conversion and rate of hydrolysis. A2 and B2: Chemical de-ashing by hydrochloric acid.

\begin{tabular}{|c|c|c|c|c|c|c|}
\hline \multicolumn{7}{|c|}{ Cellulose Conversion (\%) } \\
\hline & $\mathbf{A}$ & A2 & B & B2 & $\mathbf{C}$ & D \\
\hline Control & 2.2 & 86.3 & 14.9 & 75.6 & 62.2 & 79.3 \\
\hline XP-16 & 3.0 & 96.4 & 25.2 & 91.6 & 85.8 & 89.5 \\
\hline XP-20 & 3.0 & 96.0 & 27.6 & 89.3 & 81.7 & 91.8 \\
\hline $\mathrm{H}_{2} \mathrm{O}_{2}$ Pretreated & 1.7 & 99.3 & 40.2 & 99.0 & 97.2 & 98.6 \\
\hline \multicolumn{7}{|c|}{ Hydrolysis rate (g glucose produced/L/h) } \\
\hline & $\mathbf{A}$ & A2 & B & B2 & $\mathbf{C}$ & D \\
\hline Control & 0.00 & 1.40 & 0.05 & 0.82 & 0.12 & 0.72 \\
\hline XP-16 & 0.01 & 1.70 & 0.12 & 0.99 & 0.35 & 0.88 \\
\hline XP-20 & 0.01 & 1.70 & 0.13 & 1.00 & 0.30 & 0.92 \\
\hline $\mathrm{H}_{2} \mathrm{O}_{2}$ Pretreated & 0.00 & 1.73 & 0.15 & 1.80 & 0.43 & 1.14 \\
\hline
\end{tabular}


Table 4. Statistical analysis of chemical treatment ( $\mathrm{HCl}$ wash) - A, XP-16 addition - B, XP-20 addition $-\mathrm{C}, \mathrm{H}_{2} \mathrm{O}_{2}$ pretreatment and their interaction effects on enzymatic hydrolysis and fermentation associated performance parameters (Two-level factorial design in Design-Exper®) from Stat-ease).

\begin{tabular}{|c|c|c|c|c|c|c|c|c|c|c|c|c|c|}
\hline Response & Intercept $A$ & & $\mathbf{B}$ & C & D & $\mathbf{A B}$ & $\mathbf{A C}$ & AD & BD & CD & ACD & BCD & ABCD \\
\hline $\begin{array}{l}\text { Cellulose } \\
\text { Conversion }\end{array}$ & 28.9 & 15.5 & -14.4 & -14.4 & -11.6 & - & -7.8 & -8.1 & - & - & - & 17.7 & - \\
\hline $\mathrm{p}=$ & - & 0.01 & 0.008 & 0.008 & 0.022 & & 0.093 & 0.081 & - & - & - & 0.003 & - \\
\hline $\begin{array}{l}\text { Rate of } \\
\text { hydrolysis }\end{array}$ & 0.3 & 0.3 & -0.8 & -0.2 & -0.1 & -0.2 & -0.2 & - & -0.1 & -0.1 & -0.1 & 0.2 & 0.2 \\
\hline $\mathrm{p}=$ & - & 0.005 & 0.020 & 0.021 & 0.202 & 0.034 & 0.034 & - & 0.236 & 0.222 & 0.312 & 0.012 & 0.026 \\
\hline $\begin{array}{l}\text { Glucose } \\
\text { Conversion }\end{array}$ & 23.4 & 23.4 & -11.8 & -10.9 & -12.8 & -11.8 & -10.9 & -12.8 & - & - & - & 11.2 & - \\
\hline $\mathrm{p}=$ & - & 0.001 & 0.029 & 0.040 & 0.021 & 0.029 & 0.040 & 0.021 & - & - & - & 0.035 & - \\
\hline $\begin{array}{l}\text { Rate of Glucose } \\
\text { Consumption }\end{array}$ & 1.1 & 1.1 & -0.6 & -0.4 & -0.7 & -0.6 & -0.4 & -0.7 & - & - & - & - & 0.5 \\
\hline $\mathrm{p}=$ & - & 0.002 & 0.040 & 0.115 & 0.016 & 0.040 & 0.115 & 0.016 & - & - & - & - & 0.058 \\
\hline $\begin{array}{l}\text { Rate of Ethanol } \\
\text { Production }\end{array}$ & 0.5 & 0.5 & -0.3 & -0.2 & -0.3 & -0.3 & -0.2 & -0.3 & - & - & - & 0.2 & - \\
\hline $\mathrm{p}=$ & - & 0.003 & 0.031 & 0.213 & 0.019 & 0.031 & 0.213 & 0.019 & - & - & - & 0.099 & - \\
\hline $\begin{array}{l}\text { Final Ethanol } \\
\text { Titers }\end{array}$ & 5.9 & 5.9 & -2.9 & -2.7 & -2.9 & -2.9 & -2.7 & -2.9 & - & - & - & - & - \\
\hline $\mathrm{p}=$ & - & 0.007 & 0.118 & 0.137 & 0.114 & 0.118 & 0.137 & 0.114 & - & - & - & - & - \\
\hline
\end{tabular}


Table 5. Predicted parameters of pseudo first-order model for production rate of glucose.

\begin{tabular}{ccccc}
\hline \multirow{2}{*}{$\begin{array}{c}\text { c-PAM and } \mathbf{H}_{2} \mathbf{O}_{2} \\
\text { Pretreatment }\end{array}$} & $\begin{array}{c}\mathbf{H C l} \\
\text { treated/untreated }\end{array}$ & \multicolumn{2}{c}{$\begin{array}{c}\text { Pseudo first-order } \\
\text { model } \\
\mathbf{d} \boldsymbol{C} / \mathbf{d} t=\boldsymbol{k}\left(\boldsymbol{C}_{\mathbf{e}}-\boldsymbol{C}\right)\end{array}$} & $\begin{array}{c}\mathbf{R}^{\mathbf{2}} \\
\mathbf{( - )}\end{array}$ \\
\cline { 3 - 5 } & $\boldsymbol{k}\left(\mathbf{h}^{-1}\right)$ & $\boldsymbol{C}_{\mathbf{e}}(\mathbf{g} / \mathbf{L})$ & \\
\hline \multirow{2}{*}{ Control } & untreated & 0.0477 & 1.86 & 0.9202 \\
& treated & 0.0694 & 19.8 & 0.9704 \\
XP16 & untreated & 0.0730 & 3.1 & 0.9731 \\
& treated & 0.0613 & 24.1 & 0.9853 \\
XP20 & untreated & 0.0669 & 3.4 & 0.9659 \\
& treated & 0.0747 & 23.3 & 0.9797 \\
$\mathrm{H}_{2} \mathrm{O}_{2}$ pretreated & untreated & 0.0635 & 4.96 & 0.9778 \\
& treated & 0.0717 & 25.9 & 0.9889 \\
\hline
\end{tabular}


Table 6. Effect of chemical de-ashing (HCl wash), c-PAM addition (XP-16 and XP-20), and $\mathrm{H}_{2} \mathrm{O}_{2}$ pretreatment on ethanol yield, final ethanol titers, and rate of glucose consumption and ethanol production on different sludge tested during fermentation by FermPro yeast.

\begin{tabular}{|c|c|c|c|c|}
\hline \multicolumn{5}{|c|}{ Ethanol Yield (g ethanol produced / g glucose) } \\
\hline & A2 & B2 & $\mathbf{C}$ & D \\
\hline Control & 0.471 & 0.477 & 0.472 & 0.469 \\
\hline XP-16 & 0.443 & 0.453 & 0.448 & 0.439 \\
\hline XP-20 & 0.483 & 0.489 & 0.488 & 0.487 \\
\hline $\mathrm{H}_{2} \mathrm{O}_{2}$ Pretreated & 0.394 & 0.413 & 0.404 & 0.385 \\
\hline \multicolumn{5}{|c|}{ Glucose rate Consumption (g glucose /L/h) } \\
\hline & A2 & B2 & $\mathbf{C}$ & D \\
\hline Control & 5.39 & 4.66 & 2.63 & 5.63 \\
\hline XP-16 & 4.72 & 4.21 & 2.71 & 4.74 \\
\hline XP-20 & 5.69 & 5.49 & 3.45 & 6.51 \\
\hline $\mathrm{H}_{2} \mathrm{O}_{2}$ Pretreated & 3.35 & 3.07 & 2.08 & 3.51 \\
\hline \multicolumn{5}{|c|}{ Ethanol Productivity (g Ethanol /L/h) } \\
\hline & A2 & B2 & $\mathbf{C}$ & D \\
\hline Control & 2.33 & 2.31 & 1.30 & 2.75 \\
\hline XP-16 & 1.88 & 1.60 & 1.01 & 1.74 \\
\hline XP-20 & 2.81 & 2.78 & 1.73 & 3.28 \\
\hline $\mathrm{H}_{2} \mathrm{O}_{2}$ Pretreated & 1.27 & 1.31 & 0.87 & 1.43 \\
\hline \multicolumn{5}{|c|}{$\begin{array}{l}\text { Final Ethanol titers" }(\mathrm{g} / \mathrm{L}) \\
\end{array}$} \\
\hline & A2 & B2 & $\mathbf{C}$ & D \\
\hline Control & 23.8 & 21.0 & 11.8 & 24.9 \\
\hline XP-16 & 26.2 & 24.1 & 15.5 & 26.3 \\
\hline XP-20 & 28.1 & 25.4 & 16.0 & 30.0 \\
\hline $\mathrm{H}_{2} \mathrm{O}_{2}$ Pretreated & 25.9 & 23.8 & 15.8 & 26.0 \\
\hline
\end{tabular}




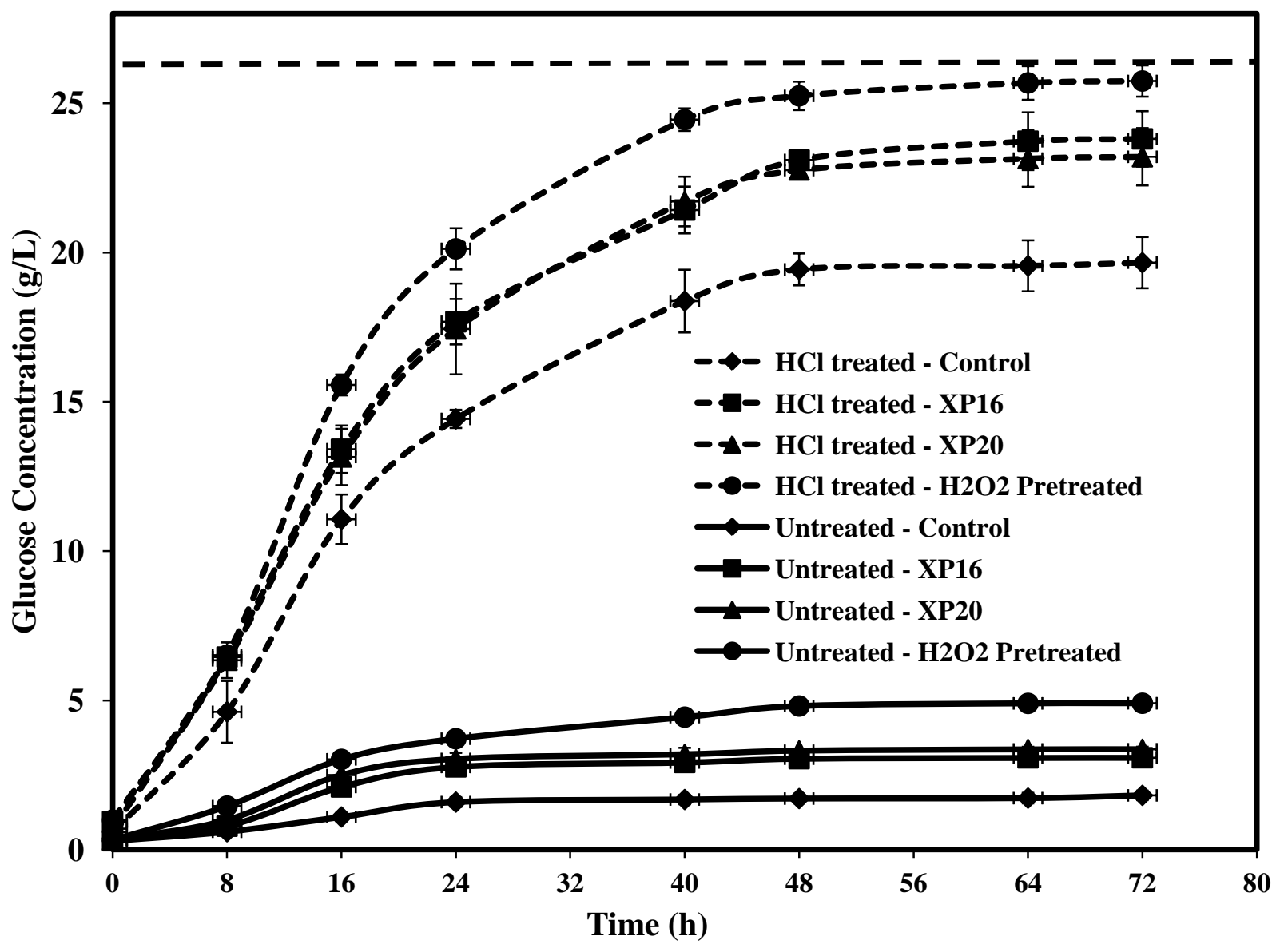

Fig. 1 
a)

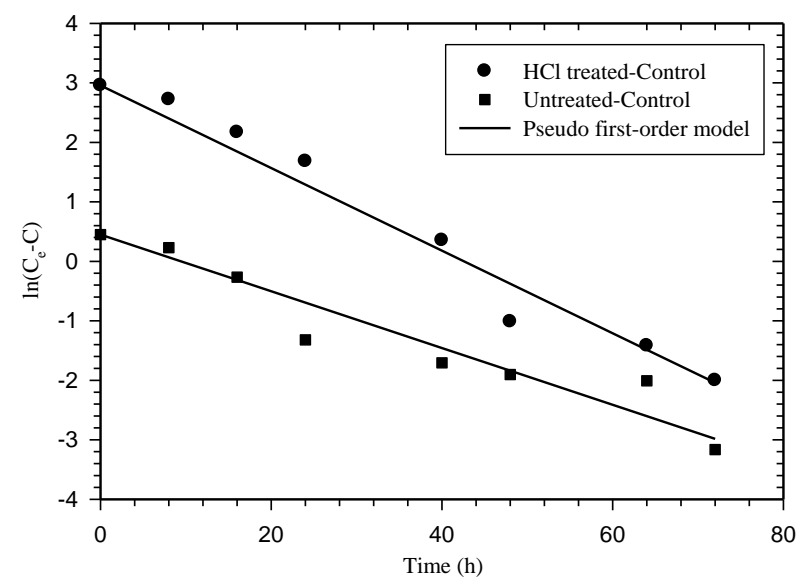

c)

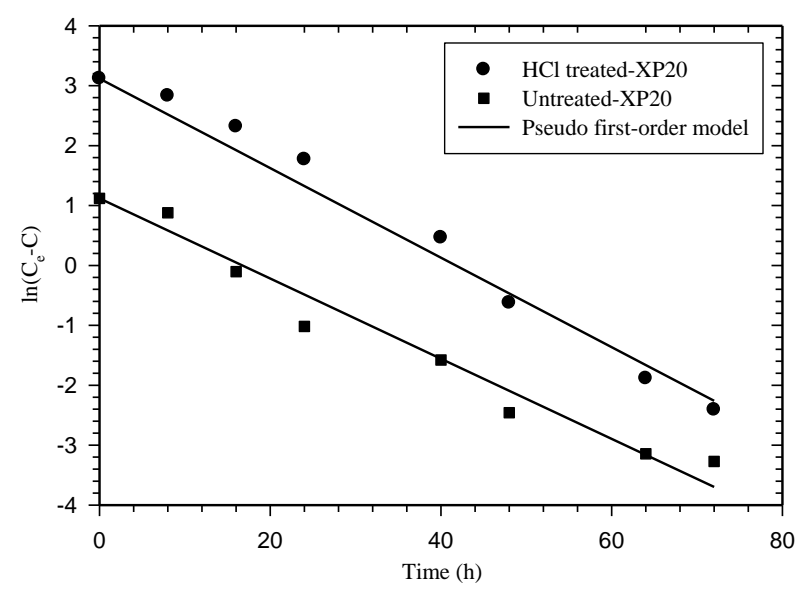

b)

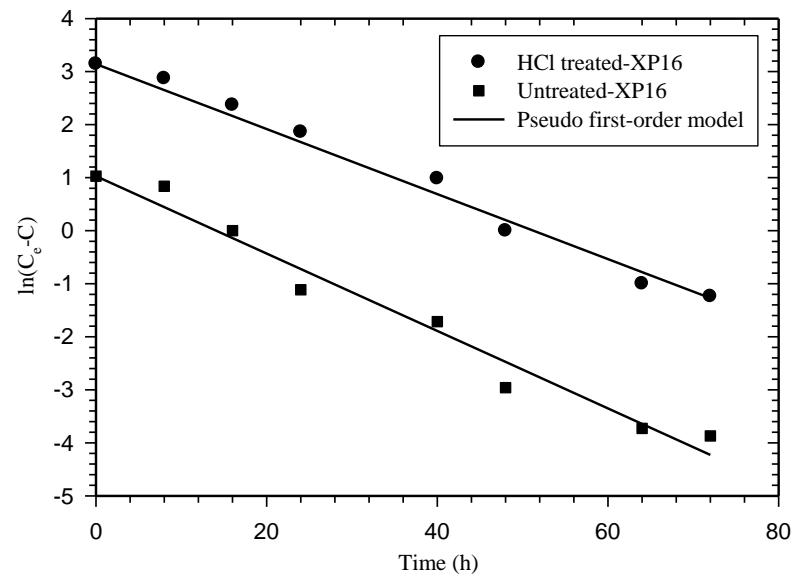

d)

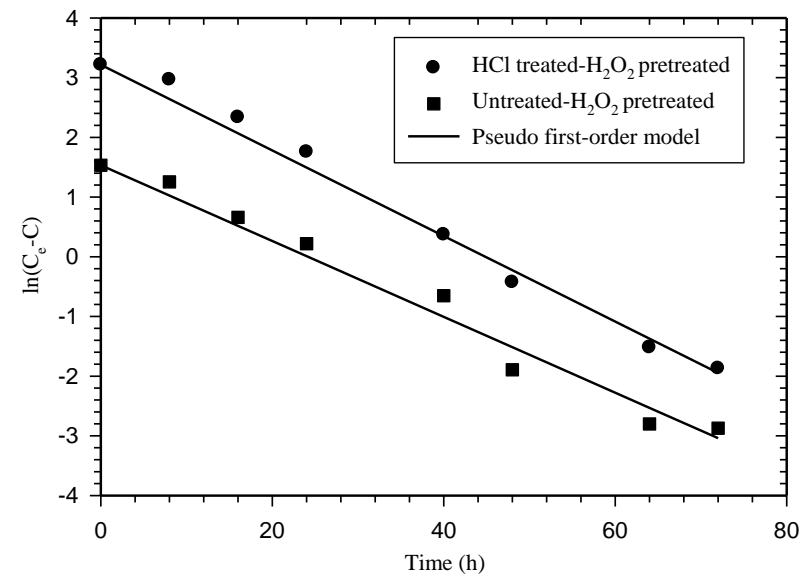

Fig. 2 


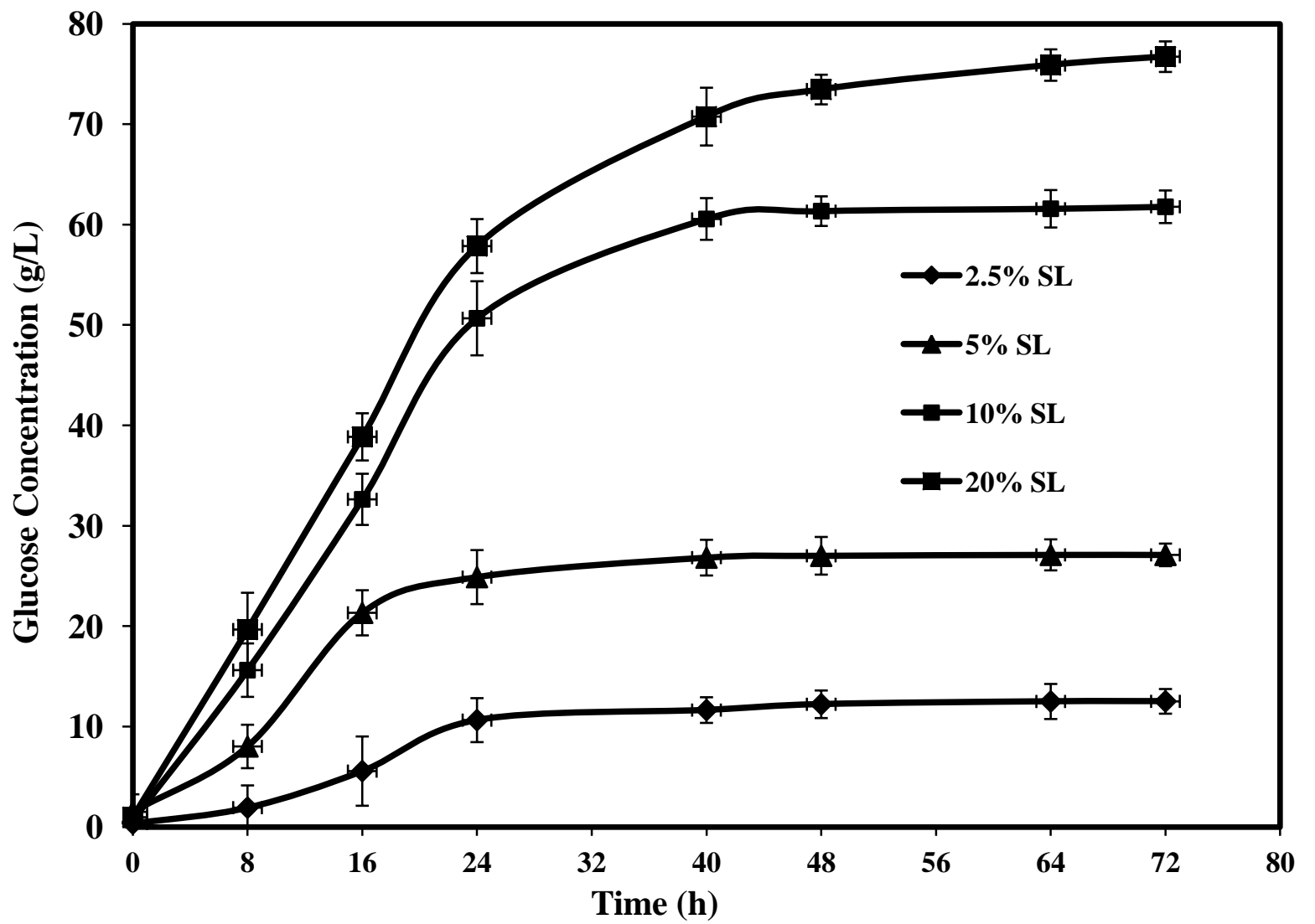

Fig. 3 


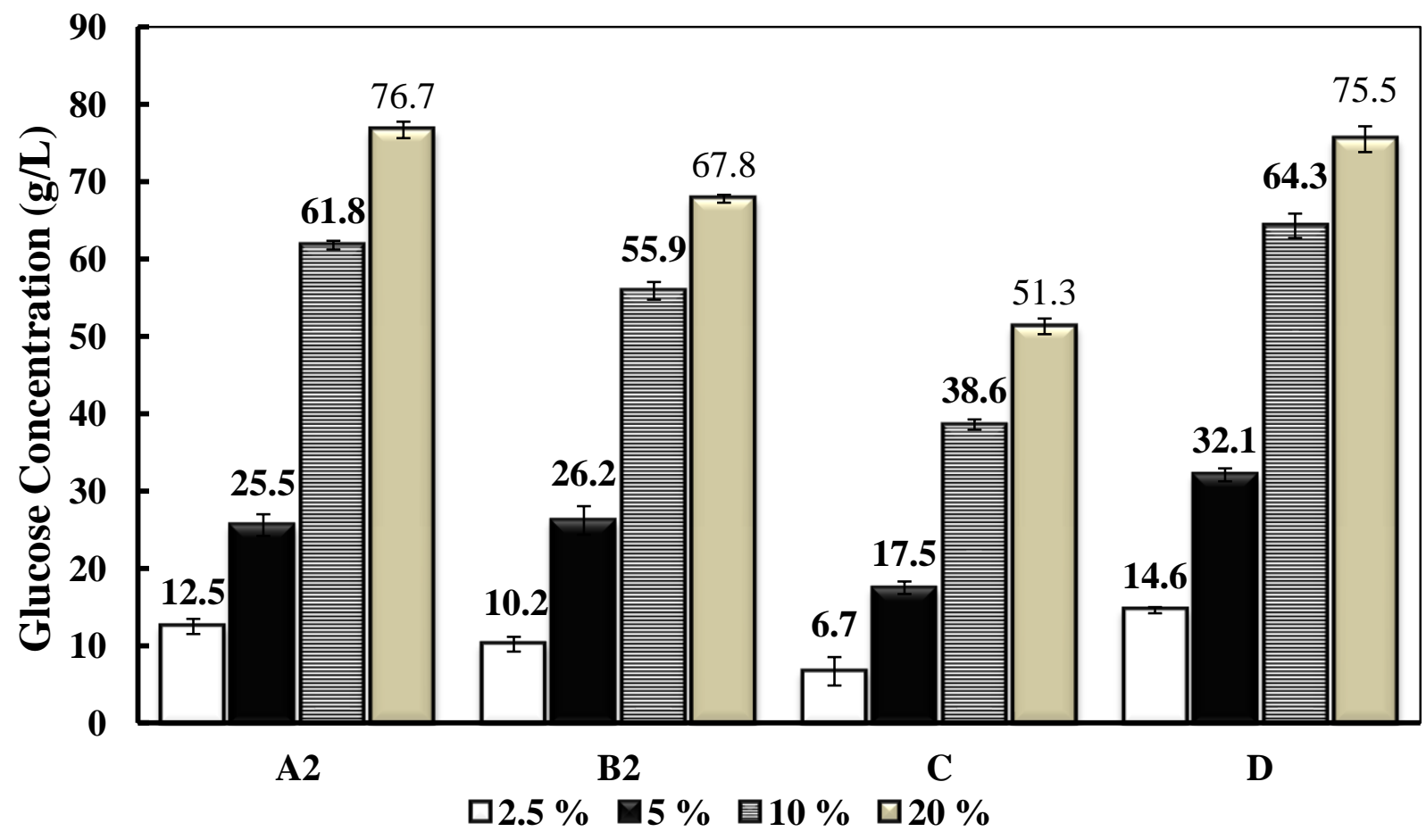

Fig. 4 


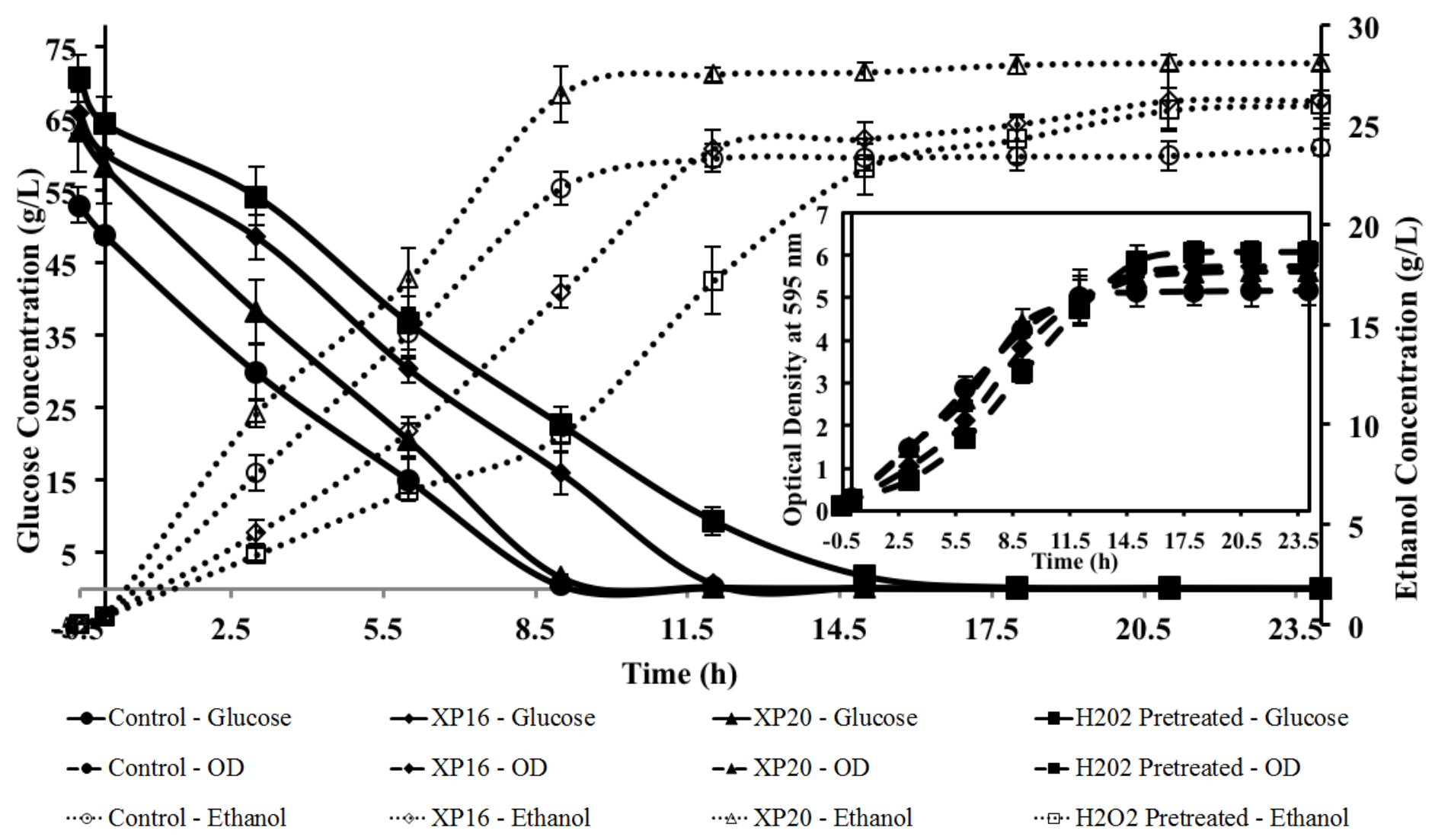

Fig. 5 


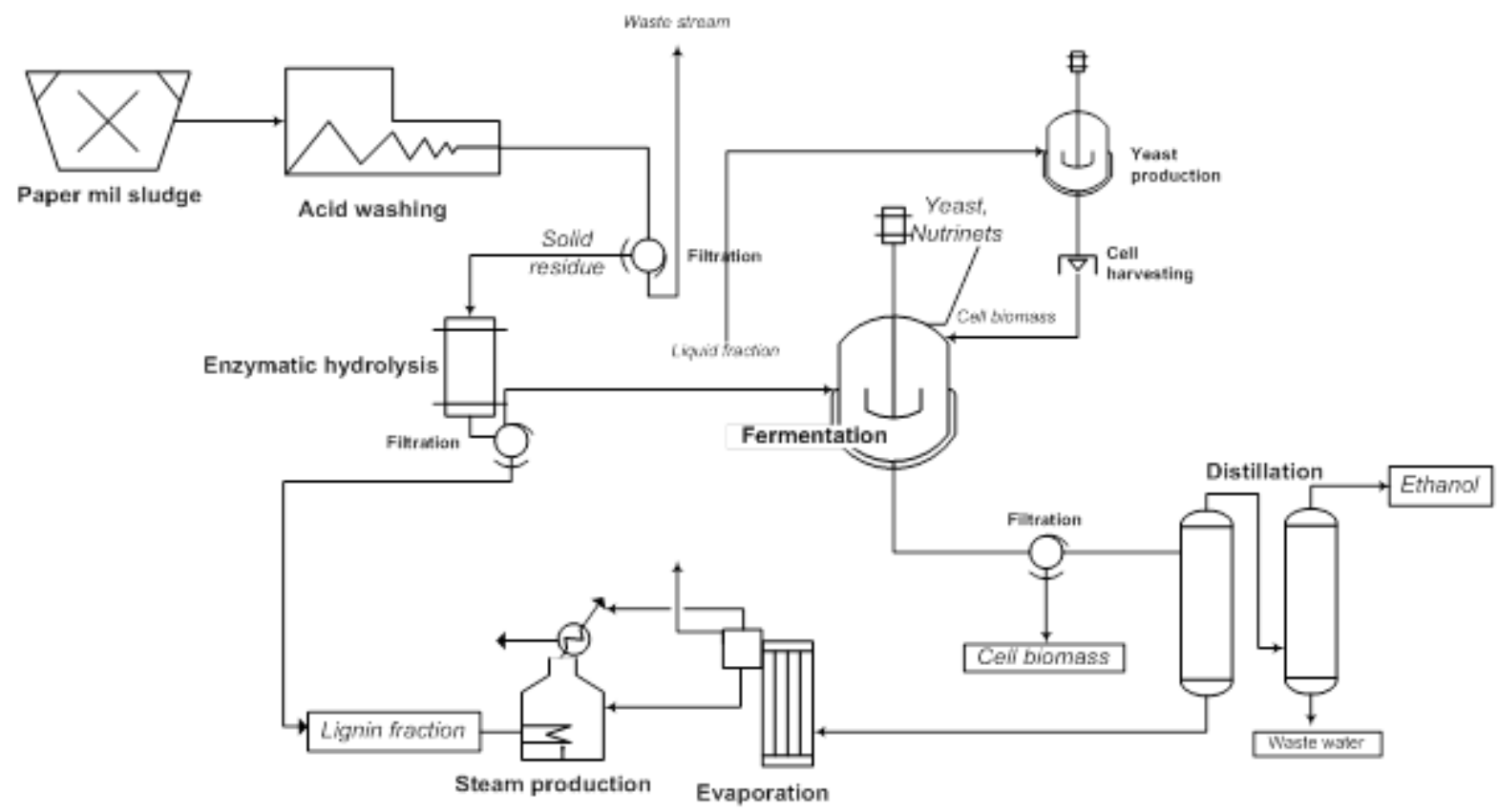

Fig. 6 